awarded him the degree of Doctor of Letters for his study of an early Indian musical text, The Mirror of Music (1930). 1925-29 he had spent in India, working at Santiniketan under Rabindranath Tagore where he came to love India and its music. He was also able to visit Nepal and study there.

After four years of research at the Kern Institute in Leiden, he was awarded a Spalding Research Fellowship (1937-44) at Brasenose College, Oxford, when he visited India for a further study of its music, acquiring a knowledge that very few Indians could emulate. A wonderful voice allowed him to illustrate with his own singing, the lectures he gave in Europe and North America.

Settling in England, in 1948 he was appointed Reader in Sanskrit in the University of London. In 1955-6 he revisited India and in Nepal recorded much unknown material, to the classification and study of which he devoted a great part of the time left to him. He contributed important chapters to the New Oxford History of Music and to several encyclopædias.

To his widow, the Society extends its respectful sympathy.

\title{
ProfesSOR EDWARD ROBERTSON
}

D.LITT., D.D. (St. Andrews), HON. D.D. (Wales), LL.D. (Manchester)

Professor and Mrs. Edward Robertson, both aged about 80 had but recently left this country to live with the family of their daughter Helen (Mrs. W. H. Morton) in the province of Quebec. In February this year Mrs. Robertson suffered an accident from which she died; a few weeks later news came of Professor Robertson's passing. Both will be missed, and both will be remembered in countless ways, for they were amazing people. They had become legendary figures of whom it was said: "What next!" Yet never has anything been said or even thought of them except in admiration and with deep affection.

Professor Robertson was born in Cameron, Fife, about $1880-$ though the actual year seems never to have emerged in Who's Who. He first showed academic promise in mathematics at St. Andrews, but soon turned to Semitic Languages, which he continued to study at German Universities and in Syria. He lectured in Arabic at Edinburgh (1913-21), then he became Professor of Semitic Languages at the University College of North Wales, Bangor (1921-34) and later held the parallel Chair at Manchester University until his 
retirement (1934-45). In 1949 he became Librarian of the John Rylands Library, Manchester, and relinquished the post in 1962 to move to Canada.

For a seemingly unobtrusive person, honours and special responsibilities fell into his lap abundantly. In Bangor he became Vice-Principal after only five years on the Senate: in Manchester the office of Pro-Vice-Chancellor (1944) was only one of a long series of duties he fulfilled to the satisfaction of all. The University of Wales retained his services as co-opted member on its Faculty of Theology, and he is still remembered with particular warmth, to judge by the obituaries written about him here. Both Universities recognized his services with the award of honorary degrees, and among Professors everywhere he is probably unique in this respect. He became President of the Society for Old Testament Studies in 1948.

He wrote with ease and enthusiasm but did not publish much. In the field of Old Testament he was controversial. The GrafWellhausen hypothesis on the composition of the Pentateuch held little attraction for him and he offered an alternative, namely that the unification of the Pentateuchal documents and also of divergent strands in early Yahwism was achieved by Samuel. The case is outlined in the The Old Testament Problem (Manchester University Press, 1950), and, though he did not succeed in convincing all the leading scholars, most of the recent Introductions to the Old Testament find room to mention the theory. A modern survey of the religious history of the Old Testament might provide a better setting for it.

But Robertson did succeed with his major publications, Catalogue of the Samaritan Manuscripts in the John Rylands Library, Manchester; vol. i. The Crawford Collection (1938), vol. ii., The Gaster Collection (1962). The story of the acquisition of the latter, given in various issues of the Bulletin of the John Rylands Library in the 1950's, shows him factual but very human, scholarly but never pedantic. The catalogue itself is generally acknowledged to be a masterpiece. The arrangement of details and the basis of the classification and the identification-marks which are discussed in the first volume are outstanding among this class of scholarly publications. His important conclusions about the recent issue of the Abisha Scroll by Perez Castro are published in a review in Vetus Testamentum, 1962.

The epithet 'The Good Samaritan' — frequently applied to him suits not only his scholarship but also his whole nature. I write as 
his old student and assistant, and recall countless kindnesses and especially the good advice he always gave me, even the last time we met, a few days before he left for Canada.

No description of him, however, can ignore his prowess in and his passion for sport. He played rugby, and missed a trial match for his international cap for Scotland only through a broken leg. Even in middle-age he could send a first service down the tennis court which was quite unreturnable. Students at Bangor used to stand watching some tough rugby football, but also observing two of their Professors on the touch-line; the one, Robertson, standing stolidly in one spot watching every move, the other, R. L. Archer, who had tragically lost the use of one eye, running up and down the line intent on the game and an embarrassment on his blind side both to the linesman and the spectators. Even during his Rylands period, Robertson could be seen watching soccer, especially Manchester United when they played at home.

The legends about Professor Robertson are usually on the practical side. He bull-dozed the Council of Bangor University College into buying a farm on the then outskirts of the city to convert into playing-fields which are now, of course, a priceless asset. I used to admire his manœuvres in Manchester, shrewd and far-seeing. In the Rylands Library he changed the heating system and got more money for the scrap than was needed to buy the whole of the new installation. The story of the way he acquired for the Library the Gaster Collection, including some trunks full of Cairo Genizah Fragments which would repay close scrutiny, is better than many a thriller. This tribute cannot be closed without a further reference to Mrs. Robertson, the successful portrait artist, Gertrude Coventry. The legends about her are always otherworldly. She had amazing charm, and she was a beautiful woman, but unbelievably vague. And he was equally gentle with her, and proud of her achievements, both as an artist and as a 'character'. They lost their son, Ian, when he was a medical student early in the war; their two daughters are married and live abroad. It grieves us to mourn the death of two such remarkable people.

BLEDDYN J. ROBERTS. 